\title{
COMPLICATIONS IN ABO-INCOMPATIBLE HEMATOPOIETIC STEM CELL TRANSPLANT IN PAKISTAN
}

\author{
Mussawair Hussain ${ }^{1}$, Imran Ullah², Nighat Shahbaz', Qamar Un Nisa Chaudhry', Mehreen Ali Khan', \\ Tariq Azam Khattak ${ }^{1}$ \\ 'Department of Hematology and Stem Cell Transplant, Armed Forces Bone Marrow Transplant Center, \\ Rawalpindi, ${ }^{2}$ District Health Office, D.I.Khan, Pakistan
}

\begin{abstract}
Background: Hematopoietic stem cell transplantation (HSCT) is therapeutic option for many blood diseases. It has increased risk of complications with incompatible pair. The objective of this study was to determine the frequency of complications in ABO-incompatible HSCT in Pakistan.

Materials \& Methods: This cross-sectional study was conducted at Armed Forces Bone Marrow Transplant Centre , Rawalpindi, Pakistan from $11^{\text {th }}$ August 2018 till $31^{\text {st }}$ March 2021. A sample of 73 ABO-incompatible HSCT patients was selected. Variables were sex, age groups, acute \& delayed hemolysis, pure red cell aplasia and acute GvHD. All variables being categorical were described by count and percentage with $80 \% \mathrm{Cl}$. Complications in sample vs. population were compared through chi-square goodness of fit test.
\end{abstract}

RESULTS: Seventy three patients with ABO-incompatible HSCT included 52 (71.23\%) men \& 21 (28.77\%) women, and $49(67.12 \%)$ in age group $\leq 14$ years $\& 24(32.88 \%)$ in $\geq 15$ years. Out of 73 patients, eight $(10.96 \%)$ had acute hemolysis, $26(35.62 \%)$ had delayed hemolysis, four $(5.84 \%)$ had pure red cell aplasia and $34(46.58 \%)$ had acute GvHD. The observed prevalence in sample was similar to population for acute $(p=.46893)$ and delayed hemolysis $(p=.30759)$ and acute GvHD $(p=.55841)$, while it was different for pure red cell aplasia $(p=.00006)$.

CONCLUSION: Most common complication in our study was acute GvHD, followed by delayed hemolysis, acute hemolysis \& pure red cell aplasia. The observed prevalence in sample was similar to population for acute \& delayed hemolysis and acute GvHD, while it was different for pure red cell aplasia.

KEYWORDS: Complications; Blood Group Incompatibility; Hematopoietic Stem Cell Transplantation; Population; Sex; Age Groups; Hemolysis; Pure Red Cell Aplasia; Graft Versus Host Disease; Pakistan.

Cite as: Hussain M, Ullah I, Shahbaz N, Chaudhry QUN, Khan MA, Khattak TA. Complications in ABO-incompatible hematopoietic stem cell transplant in Pakistan. Gomal J Med Sci 2021 Jul-Sep; 19(3):98-104. https://doi. org/10.46903/gjms/19.03.974

\section{INTRODUCTION}

1.1 Background: Hematopoietic stem cell transplantation (HSCT) is treatment strategy for many hematological disorders. ${ }^{1}$ During the preceding decades, results of HSCT have improved due to better donor selection, good supportive care, improvement in post-transplant sequelae care, and recognition of less toxic procedures. Due to these changes, HSCT indications \& number of patients eligible for trans-

\section{Corresponding Author:}

Dr. Imran Ullah

Medical Specialist

District Health Office

D.I.Khan, Pakistan

E-mail: drimranullah89@gmail.com

Date Submitted: 10-04-2021

Date Revised: $\quad 18-06-2021$

Date Accepted: $\quad 28-06-2021$ plant increased globally. ${ }^{2}$

HSCT can be carried out in ABO blood group incompatible pair. ${ }^{3} \mathrm{ABO}$ incompatibility is found in $30-40 \%$ of human leukocyte antigen (HLA) matched transplants. ${ }^{4} \mathrm{ABO}$-incompatible patients are divided into three different groups: major, minor and bidirectional ABO mismatch, with incidence of $15-20 \%, 15-20 \%$ and up to $5 \%$, respectively. ${ }^{5}$

Complications like acute and delayed hemolysis, pure red cell aplasia (PRCA) and acute graft vs. host disease (GvHD) were found in ABO-incompatible HSCT affecting the outcome of transplant and required additional strategies in terms of graft manipulation and post-transplant management. ${ }^{3,6-9}$

Zhu, et el. ${ }^{6}$ reported from China for the period from April 1997 to December 200642 ABO-incompatible HSCT cases, including 13 bone marrow transplant, 25 peripheral blood stem cell \& four cord blood, and 29 grafts from related \& 13 from unrelated donors. 
He reported $26.19 \%(11 * 100 / 42=26.19 \%)$ PRCA and $50 \%(21 * 100 / 42=50)$ acute GvHD in this sample.

Vaezi, et al. ${ }^{7}$ from Tehran, Iran reported 486 total allogenic HSCT from 2010 to 2012, including 203 ABO-incompatible transplants, having $49.26 \%$ $(100 * 100 / 203=49.26)$ acute GvHD $\geq \mathrm{Il}$.

Aung, et al. ${ }^{8}$ from Texas for the period from January 2007 to December 2008 reported $7.45 \%$ $(12 * 100 / 161=7.45)$ frequency of PRCA in 161 major ABO incompatible transplants out of 596 HSCT.

Tomac, et al ${ }^{9}$ from Zagreb, Croatia from 2012 to 2013

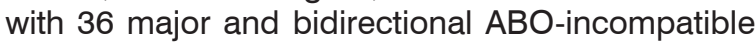
HSCT demonstrated $13.89 \%(5 * 100 / 36=13.89)$ acute hemolysis and $2.78 \%(1 * 100 / 36=2.78)$ PRCA, with no delayed hemolysis.

Worel, et al. ${ }^{3}$ from Vienna, Austria reported 30\% prevalence of delayed hemolysis in minor ABO-incompatible HSCT in a review article published in October 2015.

1.2 Research Objectives (RO 1-4): To determine the prevalence of acute \& delayed hemolysis, pure red cell aplasia and acute GvHD in ABO-incompatible HSCT in Pakistan.

\subsection{Research Hypotheses (Null)}

$\mathbf{H}_{01}$ : The observed prevalence of acute hemolysis is good fitting to its expected prevalence in ABO-incompatible HSCT in Pakistan. (RO1)

$\mathbf{H}_{02}$ : The observed prevalence of delayed hemolysis is good fitting to its expected prevalence in ABO-incompatible HSCT in Pakistan. (RO2)

$\mathrm{H}_{03}$ : The observed prevalence of pure red cell aplasia is good fitting to its expected prevalence in ABO-incompatible HSCT in Pakistan. (RO3)

$\mathbf{H}_{04}$ : The observed prevalence of acute GvHD is good fitting to its expected prevalence in $\mathrm{ABO}$-incompatible HSCT in Pakistan. (RO4)

1.4 Significance: HSCT is relatively advanced therapeutic procedure in Pakistan; that has evolved in the preceding two decades. This study will provide data regarding the magnitude of the complications in our local population. It will also create background data for future research and will help in determining future trends of the complications.

\subsection{Operational Definitions}

Major ABO mismatch: "When the recipient serum contains antibodies directed against donor red blood cell antigens". ${ }^{5}$

Minor ABO mismatch: "When the donor serum contains antibodies against recipient red blood cell antigens". ${ }^{5}$

Bidirectional ABO mismatch: "When both the recipient \& donor sera contain antibodies directed against the donor and the recipient red blood cell antigens respectively". ${ }^{5}$
Acute hemolysis: "Hemolysis occurring within 7 days after ABO-incompatible HSCT". ${ }^{3}$

Delayed hemolysis: "Hemolysis occurring 7 days after ABO-incompatible HSCT". 3,10,11

Pure red cell aplasia: "Pure red cell aplasia will be diagnosed when reticulocytopenia (reticulocyte count $<0.5 \%$ ) persists, bone marrow biopsy shows sufficient myeloid, lymphoid and megakaryocytic populations with absent erythroid precursors and the recipient is red cell transfusion-dependent more than 30 days after HSCT" ${ }^{6,9}$

Acute GvHD: "Classified and graded according to the Glucksberg-Seattle criteria". ${ }^{12}$

\section{MATERIALS AND METHODS}

2.1 Study Design, Settings \& Duration: This cross-sectional study was conducted from $11^{\text {th }} \mathrm{Au}$ gust 2018 till $31^{\text {st }}$ March 2021 at Armed Forces Bone Marrow Transplant Center, Rawalpindi, Pakistan. It is the second of nine centres of its type in Pakistan. It caters for about $42 \%$ of bone marrow transplants from all over the country. Permission from Hospital Ethical Committee was sought prior to commencement of study. Informed consent was taken from the patients/ parents for inclusion in the study.

2.2 Population \& Sampling: We assumed 100 annual ABO-incompatible HSCT cases in nine transplant centres of Pakistan. Complications like acute GvHD of $50 \%$ in this population was anticipated. Online calculator Raosoft ${ }_{\circledast}^{13}$ gave us sample of 73 with $6 \%$ margin of error at $95 \% \mathrm{CL}$. Consecutive non-probability sampling method was employed. All $\mathrm{ABO}$-incompatible HSCT cases were eligible.

2.3 Conduct of Procedure: Informed consent was taken from the patients/ parents before undergoing transplant. In patients less than 18 years of age consent was taken from parents. Following procedures were done before HSCT

i. ABO blood group testing \& HLA matching of donor and recipient

ii. Chemotherapy to recipient was given, where indicated

iii. Conditioning regimen was given to recipient

iv. GvHD prophylaxis to recipient was given

v. For all major ABO-incompatible HSCTs, the stem cell product was red cell-depleted.

vi. For bidirectional ABO-incompatible HSCTs, the stem cell product was red cell- and plasma-depleted

vii. Plasma depletion was done in only one patient for minor $A B O$ mismatch because anti-recipient antibody titer was 1:256.

viii. Antibiotics, antiviral and antifungal prophylaxis were given to recipient where indicated.

Detail history, examination and necessary inves- 
tigations were done to detect complications in ABO-incompatible HSCT. Hematopoietic recovery of neutrophil and platelet were monitored after HSCT and expressed as number of days required to reach an absolute neutrophil count of $0.5 \times 10^{9} / \mathrm{L}$ and platelet count of $20 \times 10^{9} / \mathrm{L}$ without transfusion. $\mathrm{RBC}$ and platelet transfusion requirements were assessed by recording the day of the last $\mathrm{RBC}$ and platelet transfusion and total number of transfused products during HSCT. Acute GvHD was monitored till 100 days post-HSCT.

The stem cells were taken from bone marrow harvest $(\mathrm{BMH})$ in $64(87.67 \%)$ cases, from paripheral blood stem cell (PBSC) in four (5.48\%) cases and from both $\mathrm{BMH}$ and PBSC in five (6.85\%) cases. 48 (65.75\%) patients received myeloablative conditioning regimen, 17 (23.29\%) received non-myeloablative and eight $(10.96 \%)$ received reduced intensity conditioning regimen. Processing of stem cell was done for major and bidirectional ABO mismatch. Plasma depletion was done in only one patient for minor $A B O$ mismatch because anti-recipient antibody titer was 1:256. Mean CD34 dose was $8.4 \times 10^{6} / \mathrm{kg} \pm 7.7$ and mean total nucleated cell (TNC) dose was $4.9 \times 10^{8} /$ $\mathrm{kg} \pm 1.9$. Neutrophil engraftment was achieved in $98.6 \%$ of patients at a median of day 13 post-transplant (range 10-20 days). One patient had primary graft failure. Platelet engraftment was achieved in $96 \%(n=70)$ of patients at a median of day 22 post-transplant. $91.8 \%(n=67)$ achieved red cell engraftment. Mean red cell concentrates transfused during the duration of transplant was 4 units \pm 3.6. Regarding platelet, mean number of random donor platelet units transfused was $15 \pm 16.5$ and mean number of single donor platelets was $2.8 \pm 2.6$ units.

2.4 Data Collection Plan: Data was extracted for two demographic variables; sex (men/ women) \& age group ( $\leq 14$ years/ $\geq 15$ years.), and four research variables (acute \& delayed hemolysis, PRCA \& acute GvHD). All data was binary nominal.

\subsection{Data Analysis Plan}

2.5.1 Descriptive statistics and estimation of parameters: The variables for the sample were described by count and percentage and for population as C.I (confidence interval) for proportion at $80 \%$ C.L (confidence level) taking help of online statistical calculator. ${ }^{14}$

2.5.2 Testing of Hypotheses: Difference between the observed and expected prevalence of the four research variables was validated separately by chi-square goodness of fit test through an online calculator $\left(\mathrm{H}_{01}-\mathrm{H}_{04}\right){ }^{15-17}$

\section{RESULTS}

\subsection{Descriptive statistics \& estimation of param- eters}

3.1.1 Sample description \& prevalence of complications in ABO-incompatible HSCT: Out of 73 cases, $52(71.23 \%)$ were men \& $21(28.77 \%)$ women, and $49(67.12 \%)$ were in age group $\leq 14$ years $\& 24$ $(32.88 \%)$ were in age group $\geq 15$ years.

Out of 73 cases, eight (10.96\%) had acute hemolysis, $26(35.62 \%)$ had delayed hemolysis, four $(5.84 \%)$ had pure red cell aplasia and 34 (46.58\%) had acute GvHD. Estimated prevalence in population is shown below. (Table 3.1.1)

\subsection{Hypotheses Testing:}

3.2.1 Observed vs. expected prevalence of acute hemolysis in ABO-incompatible HSCT $\left(\mathrm{H}_{01}\right)$ : Our observed findings of acute hemolysis (yes: no) were $8: 65(n=73)$ in respect to corresponding expected findings of $5: 31(n=36)$ by Tomac, et $a^{9}$. With dissimilar denominators comparability was impossible. Therefore, the denominator 36 of Tomac, et al. ${ }^{9}$ was replaced by ours denominator 73 . The expected

Table 3.1.1: Prevalence of Complications in ABO-incompatible HSCT in Pakistan $(n=73)$

\begin{tabular}{|l|c|c|c|c|c|}
\hline \multirow{2}{*}{ Research variables } & \multirow{2}{*}{ Attributes } & \multicolumn{2}{|c|}{ Sample analysis } & \multicolumn{2}{c|}{$80 \% \mathrm{Cl}$ for proportion } \\
\cline { 3 - 6 } & & Count & $\%$ age & Lower & Upper \\
\hline \multirow{2}{*}{ Presence of acute hemolysis } & Yes & 8 & 10.96 & 7.10 & 16.53 \\
\cline { 2 - 6 } & No & 65 & 89.04 & 83.47 & 92.89 \\
\hline \multirow{2}{*}{ Presence of delayed hemolysis } & Yes & 26 & 35.62 & 28.83 & 43.05 \\
\cline { 2 - 6 } & No & 47 & 64.38 & 56.95 & 71.17 \\
\hline \multirow{2}{*}{ Presence of pure red cell aplasia } & Yes & 4 & 05.48 & 2.94 & 9.98 \\
\cline { 2 - 6 } & No & 69 & 94.52 & 90.03 & 97.06 \\
\hline \multirow{2}{*}{ Presence of acute GvHD } & Yes & 34 & 46.58 & 39.26 & 54.06 \\
\cline { 2 - 6 } & No & 39 & 53.42 & 45.94 & 60.74 \\
\hline \multicolumn{2}{|c|}{ Total } & & 73 & $100 \%$ & \multicolumn{2}{c|}{ Population parameters } \\
\hline
\end{tabular}


counts of 5:31 $(n=36)$ were changed to 10.14:62.86 $(n=73)$. Adjusted expected percentages came identical to expected percentages, so not replaced. (Table 3.2.1.1)

Test of significance resulted in p-value .46893, accepting $\mathrm{H}_{01}$, which proved that the observed results match the expected results of the population. Simply, the findings of $10.96 \%$ of acute hemolysis in our population is similar to the adjusted expected findings of 13.89\% from Tomac, et $\mathrm{al}^{9}$. (Table 3.2.1.2)

3.2.2 Observed vs. expected prevalence of delayed hemolysis in ABO-incompatible HSCT $\left(\mathrm{H}_{02}\right)$ : Our observed findings of delayed hemolysis (yes: no) were 26:47 $(n=73)$ in respect to corresponding assumed expected counts of 22:51 from assumed sample of 73 as reported by Worel, et al. ${ }^{3}$ from Vienna, Austria in a review article published in October 29, 2015 as $30 \%$ prevalence of delayed hemolysis in minor ABOincompatible HSCT. As assumed denominator were similar to our denominator, so adjusted expected counts and percentages were not calculated. (Table 3.2.2.1)

Test of significance resulted in p-value .30759 , accepting $\mathrm{H}_{02}$, which proved that the observed results match the expected results of the population. Simply, our findings of $35.62 \%$ of delayed hemolysis is similar to the expected findings of $30.14 \%$ from Worel, et al. ${ }^{3}$ (Table 3.2.2.2)

Table 3.2.1.1: Observed, expected and adjusted expected counts and percentages for prevalence of acute hemolysis in indoor ABO-incompatible HSCT in Pakistan $(n=73)$

\begin{tabular}{|l|c|c|c|c|c|c|}
\hline $\begin{array}{l}\text { Presence of } \\
\text { acute hemolysis }\end{array}$ & $\begin{array}{c}\text { Observed } \\
\text { counts }\end{array}$ & $\begin{array}{c}\text { Observed } \\
\text { \%ages }\end{array}$ & $\begin{array}{c}\text { Expected } \\
\text { counts }\end{array}$ & $\begin{array}{c}\text { Expected } \\
\text { \%ages }\end{array}$ & $\begin{array}{c}\text { Adjusted expected } \\
\text { counts }\end{array}$ & $\begin{array}{c}\text { Adjusted expected } \\
\text { \%ages }\end{array}$ \\
\hline Yes & 08 & 10.96 & 5 & 13.89 & $5 * 73 / 36=10.14$ & $10.14 * 100 / 73=13.89$ \\
\hline No & 65 & 89.04 & 31 & 86.11 & $31 * 73 / 36=62.86$ & $62.86 * 100 / 73=86.11$ \\
\hline Total $(n)$ & 73 & $100 \%$ & 36 & $100 \%$ & 73 & $100 \%$ \\
\hline
\end{tabular}

Table 3.2.1.2: Observed vs. expected prevalence of acute hemolysis in ABO-incompatible HSCT in Pakistan $(n=73)$

\begin{tabular}{|l|c|c|c|c|c|c|}
\hline Attributes & Observed count $(\mathrm{O})$ & Expected count $(\mathrm{E})$ & $\mathrm{O}-\mathrm{E}$ & $(\mathrm{O}-\mathrm{E})^{2}$ & $X^{2}$ & $\mathrm{p}$-value \\
\hline Yes & 08 & 10.14 & -2.14 & 4.58 & 0.45 & \multirow{2}{*}{.46893} \\
\cline { 1 - 6 } No & 65 & 62.86 & 2.14 & 4.58 & 0.07 & \\
\hline Total & 73 & 73.00 & 00 & $\Sigma \chi^{2}$ & 0.52 & \multirow{2}{*}{ d.f. $=1$} \\
\hline
\end{tabular}

Table 3.2.2.1: Observed and expected counts and percentages for prevalence of delayed hemolysis in ABO-incompatible HSCT in Pakistan $(n=73)$

\begin{tabular}{|l|c|c|c|c|}
\hline Presence of delayed hemolysis & Observed counts & Observed \%ages & Expected counts & Expected \%ages \\
\hline Yes & 26 & 35.62 & 22 & 30.14 \\
\hline No & 47 & 64.38 & 51 & 69.86 \\
\hline Total $(n)$ & 73 & $100 \%$ & 73 & $100 \%$ \\
\hline
\end{tabular}

Table 3.2.2.2: Observed vs. expected prevalence of delayed hemolysis in indoor ABO-incompatible HSCT population, Pakistan $(n=73)$

\begin{tabular}{|l|c|c|c|c|c|c|c|}
\hline Variable & Attributes & $\begin{array}{c}\text { Observed count } \\
(\mathrm{O})\end{array}$ & $\begin{array}{c}\text { Expected count } \\
(\mathrm{E})\end{array}$ & $\mathrm{O}-\mathrm{E}$ & $(\mathrm{O}-\mathrm{E})^{2}$ & $\chi^{2}$ & $\mathrm{p}$-value \\
\hline \multirow{3}{*}{$\begin{array}{l}\text { Presence of delayed } \\
\text { hemolysis }\end{array}$} & Yes & 26 & 22 & 4.00 & 16.00 & 0.73 & \multirow{2}{*}{.30759} \\
\cline { 2 - 9 } & No & 47 & 51 & -4.00 & 16.00 & 0.31 & \\
\cline { 2 - 8 } & Total & 73 & 73 & 00 & $\Sigma \chi^{2}$ & 1.04 & d.f. $=1$ \\
\hline
\end{tabular}


Table 3.2.3.1: Observed, expected and adjusted expected counts and percentages for prevalence of pure red cell aplasia in indoor ABO-incompatible HSCT in Pakistan $(n=73)$

\begin{tabular}{|l|c|c|c|c|c|c|}
\hline $\begin{array}{l}\text { Presence of pure } \\
\text { red cell aplasia }\end{array}$ & $\begin{array}{c}\text { Observed } \\
\text { counts }\end{array}$ & $\begin{array}{c}\text { Observed } \\
\text { \%ages }\end{array}$ & $\begin{array}{c}\text { Expected } \\
\text { counts }\end{array}$ & $\begin{array}{c}\text { Expected } \\
\text { \%ages }\end{array}$ & $\begin{array}{c}\text { Adjusted expect- } \\
\text { ed counts }\end{array}$ & $\begin{array}{c}\text { Adjusted expected } \\
\text { \%ages }\end{array}$ \\
\hline Yes & 4 & $5.48 \%$ & 11 & $26.19 \%$ & $11^{*} 73 / 42=19.12$ & $19.12 * 100 / 73=26.19 \%$ \\
\hline No & 69 & $94.52 \%$ & 31 & $73.81 \%$ & $31^{*} 73 / 42=53.88$ & $53.88 * 100 / 73=73.81 \%$ \\
\hline Total $(n)$ & 73 & $100.00 \%$ & 42 & $100.00 \%$ & 73.00 & $100.00 \%$ \\
\hline
\end{tabular}

Table 3.2.3.2: Observed vs. expected prevalence of pure red cell aplasia in indoor ABO-incompatible HSCT in Pakistan $(n=73)$

\begin{tabular}{|l|c|c|c|c|c|c|c|}
\hline Variable & Attributes & $\begin{array}{c}\text { Observed } \\
\text { count (O) }\end{array}$ & $\begin{array}{c}\text { Expected } \\
\text { count (E) }\end{array}$ & O-E & $(\mathrm{O}-\mathrm{E})^{2}$ & $\chi^{2}$ & p-value \\
\hline \multirow{2}{*}{$\begin{array}{l}\text { Presence of pure } \\
\text { red cell aplasia }\end{array}$} & Yes & 4 & 19.12 & -15.12 & 288.61 & 11.96 & \multirow{2}{*}{00006} \\
\cline { 2 - 9 } & No & 69 & 53.88 & 15.12 & 288.61 & 04.24 & \multirow{2}{*}{ d.f. $=1$} \\
\cline { 2 - 8 }
\end{tabular}

Table 3.2.4.1: Observed, expected and adjusted expected counts and percentages for prevalence of acute GvHD in ABO-incompatible HSCT in Pakistan $(n=73)$

\begin{tabular}{|l|c|c|c|c|c|c|}
\hline $\begin{array}{l}\text { Presence of } \\
\text { acute GvHD }\end{array}$ & $\begin{array}{c}\text { Observed } \\
\text { counts }\end{array}$ & $\begin{array}{c}\text { Observed } \\
\% \text { ages }\end{array}$ & $\begin{array}{c}\text { Expected } \\
\text { counts }\end{array}$ & $\begin{array}{c}\text { Expected } \\
\text { \%ages }\end{array}$ & $\begin{array}{c}\text { Adjusted expected } \\
\text { counts }\end{array}$ & $\begin{array}{c}\text { Adjusted expected } \\
\% \text { ages }\end{array}$ \\
\hline Yes & 34 & 46.58 & 21 & 50 & $21 * 73 / 42=36.50$ & $36.50 * 100 / 73=50$ \\
\hline No & 39 & 53.42 & 21 & 50 & $21 * 73 / 42=36.50$ & $36.50 * 100 / 73=50$ \\
\hline Total $(n)$ & 73 & $100 \%$ & 42 & $100 \%$ & 73.00 & $100 \%$ \\
\hline
\end{tabular}

Table 3.2.4.2: Observed vs. expected prevalence of acute GvHD in ABO-incompatible HSCT in Pakistan $(n=73)$

\begin{tabular}{|l|c|c|c|c|c|c|c|}
\hline Variable & Attributes & Observed count (O) & Expected count $(E)$ & O-E & $(O-E)^{2}$ & $\chi^{2}$ & $p$-value \\
\hline \multirow{3}{*}{$\begin{array}{l}\text { Presence of } \\
\text { acute GvHD }\end{array}$} & Yes & 34 & 36.50 & -2.5 & 6.25 & 0.17 & \multirow{2}{*}{.55841} \\
\cline { 2 - 8 } & No & 39 & 36.50 & 2.5 & 6.25 & 0.17 & \\
\cline { 2 - 8 } & Total & 73 & 73.00 & 00 & $\Sigma \chi^{2}$ & 0.34 & d.f. $=1$ \\
\hline
\end{tabular}

3.2.3 Observed vs. expected prevalence of pure red cell aplasia in ABO-incompatible HSCT in Pakistan $\left(\mathrm{H}_{03}\right)$ : Our observed findings of pure red cell aplasia (yes: no) were 4:69 $(n=73)$ in respect to expected findings of 11:31 $(n=42)$ from Zhu, et al. ${ }^{6}$ With dissimilar denominators comparability was impossible. Therefore, the denominator 42 of Zhu, et al. ${ }^{6}$ were replaced by ours denominator 73 . The expected counts of 11:31 were replaced by 19.12:53.88. Adjusted expected percentages came identical to expected percentages, so not changed. (Table 3.2.3.1)

Test of significance resulted in $p$-value $<.00006$, rejecting $\mathrm{H}_{01}$, which proved that the observed results did not match the expected results of the population. Simply, our findings of $5.48 \%$ of pure red cell aplasia is different from the adjusted expected findings of 26.19\% from Zhu, et al. ${ }^{6}$ (Table 3.2.3.2)
3.2.4 Observed vs. expected prevalence of acute GvHD in ABO-incompatible HSCT $\left(\mathbf{H}_{05}\right)$ : Our observed findings of acute GvHD (yes: no) was 34:39 $(n=73)$ in respect to corresponding expected findings of 21:21 $(n=42)$ from Zhu, et al. ${ }^{6}$ With dissimilar denominators, comparability was impossible. Therefore, the denominator 42 of Zhu, et al. ${ }^{6}$ were replaced by ours denominator 73 . The expected counts of $21: 21$ were replaced by 36.50:36.50. Adjusted expected percentages came identical to expected percentages, so not changed. (Table 3.2.4.1)

Test of significance resulted in p-value .5584 , accepting $\mathrm{H}_{01}$, which proved that the observed results match the expected results of the population. Simply, our findings of $46.58 \%$ of acute GvHD is similar to the adjusted expected findings of $50 \%$ from Zhu, et al. ${ }^{6}$ (Table 3.2.4.2) 


\section{DISCUSSION}

4.1 Prevalence of acute hemolysis in ABO-incompatible HSCT $\left(\mathrm{H}_{01}\right)$ : Our findings $(n=73)$ disclosed $10.96 \%(7.10 \%-16.53 \%$ at $80 \% \mathrm{CL})$ acute hemolysis. Tomac, et al. ${ }^{9}(n=36)$ documented similar findings $13.89 \%$. No data reporting different results/ findings from ours could be recovered from published studies.

Our observed findings of $10.96 \%$ acute hemolysis was similar $(p=.46893)$ to what we expected as $13.89 \%$ from Tomac, et al. ${ }^{9}(n=36)$.

4.2 Prevalence of delayed hemolysis in ABOincompatible HSCT $\left(\mathbf{H}_{02}\right)$ : Our findings $(n=73)$ disclosed $35.62 \%(28.83 \%-43.05 \%$ at $80 \% \mathrm{CL})$ delayed hemolysis.

Worel, et al. ${ }^{3}$ reported similar findings $30.14 \%$ in minor ABO-incompatible HSCT. Tomac, et al. ${ }^{9}(n=36)$ revealed no delayed hemolysis. No data reporting higher results/ findings from ours could be recovered from published studies.

Our observed findings of $35.62 \%$ delayed hemolysis was similar $(p=.30759)$ to what we assumed as $30.14 \%$ from Worel, et al. ${ }^{3}$

4.3 Prevalence of pure red cell aplasia in ABOincompatible HSCT $\left(\mathrm{H}_{03}\right)$ : Our findings disclosed $5.48 \%(2.94 \%-9.98 \%$ at $80 \% \mathrm{CL})$ pure red cell aplasia $(n=73)$.

Aung, et al. ${ }^{8}(n=161)$ revealed similar findings $7.45 \%$. Lower prevalence of $2.78 \%$ than ours were reported by Tomac, et al. ${ }^{9}(n=36)$. Higher prevalence of $26.19 \%$ than ours was reported by Zhu, et al. ${ }^{6}(n=42)$.

Our observed findings of $5.48 \%$ PRCA $(n=73)$ was not similar $(p=.00006)$ to what we expected as $26.19 \%$ from Zhu, et al. ${ }^{6}(n=42)$.

4.4 Prevalence of acute GvHD in ABO-incompatible HSCT $\left(\mathrm{H}_{04}\right)$ : Our findings $(n=73)$ disclosed $46.58 \%$ (39.26\%-54.06\% at $80 \% \mathrm{CL})$ acute GvHD. Similar findings were reported by Zhu, et al. ${ }^{6}(n=42)$ $50 \%$ and Vaezi, et al. ${ }^{7}(n=203) 49.26 \%$. No data reporting different results/ findings from ours could be recovered from published studies.

Our observed findings of $46.58 \%$ acute GvHD was similar $(p=.55841)$ to what we expected as $50 \%$ from Zhu, et al. ${ }^{6}(n=42)$.

4.5 Marwat Logical Trajectory of Research Process: We have adapted this trajectory in this project. ${ }^{18-22}$

\section{CONCLUSION}

Most prevalent complication in ABO-incompatible HSCT was acute GvHD, followed by delayed hemolysis, acute hemolysis \& pure red cell aplasia. The observed prevalence in sample was similar to population for acute \& delayed hemolysis and acute GvHD, while it was different for pure red cell aplasia in ABO-incompatible HSCT.

Acknowledgment: Dr. Muhammad Marwat from Gomal Medical College, D.I.Khan is highly appreciated \& acknowledged to permit us to make use of his "Marwat Logical Trajectory of Research Process" in this project.

\section{REFERENCES}

1. Duarte RF, Labopin M, Bader P, Basak GW, Bonini $\mathrm{C}$, Chabannon $\mathrm{C}$ et, al. Indications for hematopoietic stem cell transplantation for hematological diseases, solid tumors and immune disorders: current practice in Europe, 2019. Bone marrow transplant 2019 Oct; 54(10):1525-52. https://doi. org/10.1038/s41409-019-0516-2

2. Gooley TA, Chien JW, Pergam SA, Hingorani S, Sorror ML, Boeckh M, etal. Reduced mortality after allogeniec hematopoietic-cell transplantation. N Engl J Med 2010 Nov 25; 363(22):2091-101. https://doi.org/10.1056/NEJMoa1004383

3. Worel N. ABO-Mismatched Allogeniec Hematopoietic Stem Cell Transplantation. Transfus Med Hemother 2016 Jan; 43(1):3-12. Epub 2015 Oct 29. PMID: 27022317; PMCID: PMC4797460. https://doi.org/10.1159/000441507

4. Seebach JD, Stussi G, Passweg JR, Loberiza Jr FR, Gajewski JL, Keating A et, al. ABO blood group barrier in allogeniec bone marrow transplantation revisited. Biol. Blood Marrow Transplant.. 2005 Dec 1; 11(12):1006-13. https://doi. org/10.1016/j.bbmt.2005.07.015

5. Watz E, Remberger M, Ringden O, Lundahl J, Ljungman P, Mattsson J et, al. Analysis of donor and recipient $A B O$ incompatibility and antibody-associated complications after allogeniec stem cell transplantation with reduced-intensity conditioning. Biol. Blood Marrow Transplant. 2014 Feb 1; 20(2):264-7. https://doi.org/10.1016/j. bbmt.2013.11.011

6. Zhu KE, Li JP, Zhang T, Zhong J, Chen J. Clinical features and risk factors of pure red cell aplasia following major ABO-Incompatible allogeniec hematopoietic stem cell transplantation. Hematology 2007 Apr; 12(2):117-21. PMID: 17454192. https://doi.org/10.1080/10245330601111540

7. Vaezi M, Oulad Dameshghi D, Souri M, Setarehdan SA, Alimoghaddam K, Ghavamzadeh A. ABO Incompatibility and Hematopoietic Stem Cell Transplantation Outcomes. Int J Hematol Oncol Stem Cell Res 2017 Apr 1; 11(2):139-147. PMID: 28875009; PMCID: PMC5575727.

8. Aung FM, Lichtiger B, Bassett R, Liu P, Alousi A, Bashier $Q$, et al. Incidence and natural history of pure red cell aplasia in major ABO-mismatched hematopoietic cell transplantation. Br J Haematol. 2013 Mar; 160(6):798-805. Epub 2013 Jan 18. PMID: 23330820; PMCID: PMC4078723. https:// doi.org/10.1111/bjh.12210

9. Tomac G, Bojanić I, Mazić S, Vidović I, Raos M, Ćepulić BG, et al. Haemolysis, pure red cell aplasia and red cell antibody formation associated with major and bidirectional $\mathrm{ABO}$-incompatible hematopoietic stem cell transplantation. Blood Transfus 2018 Jul; 16(4):397-404. Epub 2017 Apr 19. PMID: 28488966 ; PMCID: PMC6034778. https://doi.org/10.2450/2017.0322-16 
10. Rowley SD. Hematopoietic stem cell transplantation between red cell Incompatible donor-recipient pairs. Bone Marrow Transplantation 2001; 28: 315-321. https://doi.org/10.1038/sj.bmt.1703135

11. Booth GS, Gehrie EA, Bolan CD, Savani BN. Clinical guide to ABO-Incompatible allogeneic stem cell transplantation. Biol Blood Marrow Transplant 2013; 19: 1152-58. https://doi.org/10.1016/j. bbmt.2013.03.018

12. Glucksberg $H$, Storb R, Fefer A, Buckner CD, Neiman PE, CliftRA, et al. Clinical manifestations of graft-versus-host diseasein human recipients of marrow from HLA matched siblingdonors. Transplantation 1974; 18(4):295-304. https://doi. org/10.1097/00007890-197410000-00001

13. Raosoft ${ }^{\circledR}$ sample size calculator [internet]. Seattle, WA, USA: Raosoft Inc.; 2004. [Accessed 2021 April 30]. Available at: http://www.raosoft. com/samplesize.html

14. Statistics Kingdom. Proportion confidence interval calculator [internet]. Statistics Kingdom; Melbourne, Australia 2007. [Accessed 2021 April 30]. Available at: http://www.statskingdom. com/41_proportion_confidence_interval.html

15. Zar JH. Biostatistical Analysis. 5th ed. New York: Prentice-Hall, Inc.

16. Daniel WW. Biostatistics: A Foundation for Analysis in the Health Sciences. 7th ed. Singapore: John Wily; 2005

17. Social Science Statistics. Statistical Tests Calculators [Internet]. [Accessed 2021 May 02]. Available at: https://www.socscistatistics.com/ tests/goodnessoffit/default2.aspx
18. Ghori MR, Khan H, Marwat M. Distribution of non-malignant hematological disorders by sex, age groups and type of disease based on bone marrow aspiration in population of Khyber Pakhtunkhwa, Pakistan. Gomal J Med Sci 2019 Apr-Jun; 17 (2): 29-36. https://doi.org/10.46903/ gjms/17.02.1926

19. Ain N, Khan S, Marwat M, Khan N, Ahmad I, Ramzan F, et al. Frequency, distribution and determinants of hypertension in adult stroke population of D.I.Khan Division, Pakistan. Gomal J Med Sci 2019 Jul-Sep; 17 (3):81-9. https://doi. org/10.46903/gjms/17.03.2076

20. Marwat M, Ahmad I, Ashiq F, AliS, ZamirS, Rehman MU, et al. Frequency, distribution and determinants of diabetes mellitus in adult acute coronary syndrome population of D.I.Khan Division, Pakistan. Gomal J Med Sci 2019 OctDec;17 (4):131-43. https://doi.org/10.46903/ gjms/17.04.2106

21. Naqvi SWA, Saeed S, Rafique A, Saeed MH, Khan $\mathrm{N}$, Khan A, et al. Prevalence and distribution of malaria by sex, age groups and species in year 2019 in suspected malarial population of district D.I.Khan, Pakistan. Gomal J Med Sci 2020 OctDec; 18(4):164-73.

22. Rashid M, Rehman $Y$, Usman $M$, Younas $M$, Bilal M, Jamil M, et al. Distribution of cutaneous leishmaniasis by sex, age groups and residence in year 2020 in cutaneous leishmaniasis population of District D.I.Khan, Pakistan. Gomal J Med Sci 2021 Jan-Mar; 19(1):28-34.

\section{CONFLICT OF INTEREST \\ Authors declare no conflict of interest. GRANT SUPPORT AND FINANCIAL DISCLOSURE None declared.}

\begin{tabular}{|c|c|}
\hline \\
\hline \multicolumn{2}{|c|}{$\begin{array}{l}\text { AUTHORS' CONTRIBUTION } \\
\text { The following authors have made substantial contributions to the manuscript as under: }\end{array}$} \\
\hline Conception or Design: & $\mathrm{MH}, \mathrm{IU}$ \\
\hline Acquisition, Analysis or Interpretation of Data: & MH, IU, NS, QUNC, MAK, TAK \\
\hline Manuscript Writing \& Approval: & MH, IU, NS, QUNC, MAK, TAK \\
\hline
\end{tabular}

